\title{
PROJECTING IMMIGRATION \\ A SURVEY OF THE CURRENT STATE OF PRACTICE AND THEORY
}

\author{
Neil Howe and Richard Jackson* \\ with contributions by \\ Rebecca Strauss and Keisuke Nakashima \\ CRR WP 2004-32 \\ Released: December 2004 \\ Draft Submitted: November 2004 \\ Center for Retirement Research at Boston College \\ 550 Fulton Hall \\ 140 Commonwealth Ave. \\ Chestnut Hill, MA 02467 \\ Tel: 617-552-1762 Fax: 617-552-1750 \\ http://www.bc.edu/crr
}

\begin{abstract}
* Neil Howe is a senior associate at the Center for Strategic and International Studies (CSIS), an economist, historian, and demographer. Richard Jackson is currently a senior fellow at CSIS, where he leads the Global Aging Initiative, a research program which explores the long-term implications of population aging. The research reported herein was performed pursuant to a grant from the U.S. Social Security Administration (SSA) to the Center for Retirement Research at Boston College (CRR). The opinions and conclusions are solely those of the authors and should not be construed as representing the opinions or policy of SSA or any agency of the Federal Government or the CRR.

(C) 2004, by Neil Howe and Richard Jackson. All rights reserved. Short sections of text, not to exceed two paragraphs, may be quoted without explicit permission provided that full credit, including (C) notice, is given to the source.
\end{abstract}




\title{
About the Center for Retirement Research
}

The Center for Retirement Research at Boston College, part of a consortium that includes a parallel centers at the University of Michigan and the National Bureau of Economic Research, was established in 1998 through a grant from the Social Security Administration. The goals of the Center are to promote research on retirement issues, to transmit new findings to the policy community and the public, to help train new scholars, and to broaden access to valuable data sources. Through these initiatives, the Center hopes to forge a strong link between the academic and policy communities around an issue of critical importance to the nation's future.

\author{
Center for Retirement Research at Boston College \\ 550 Fulton Hall \\ 140 Commonwealth Ave. \\ Chestnut Hill, MA 02467 \\ phone: 617-552-1762 fax: 617-552-1750 \\ e-mail: crr@bc.edu \\ http://www.bc.edu/crr
}

\section{Affiliated Institutions:}

American Enterprise Institute

Center for Strategic and International Studies

The Brookings Institution

Massachusetts Institute of Technology

Max Planck Institute for Demographic Research

Syracuse University

Urban Institute 


\begin{abstract}
Assumptions about long-term trends in international migration are an increasingly important component of the demographic projection module. Yet most official immigration projections both in the United States and abroad rely on ad-hoc assumptions based on little theory and virtually no definable methodology. The purpose of this paper is twofold: to assess where projection-making agencies stand in their practice of immigration projection and to explore how theoretical insights about immigration may help them improve their practice. The first section describes the current projection methods of leading national and international agencies, from the U.S. Census Bureau and Social Security Administration to the United Nations and the World Bank. The second section scans the wide and varied array of "theoretical frameworks" that attempt to explain international migration flows. The paper identifies six important ones: the policy, the neoclassical, the world systems, the new economics, the social networks, and the dual labor market frameworks. We conclude that much progress might be achievable if the explanatory richness of immigration theory could somehow be consolidated and integrated into a useable projection method. The third section briefly outlines some first steps to start harnessing theory and improving practice.
\end{abstract}




\section{TABLE OF CONTENTS}

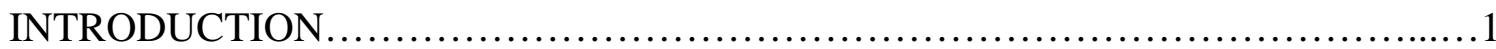

INVENTORY OF CURRENT PROJECTION PRACTICE...........................

I. Global Projections.......................................................
a. United Nations Population Division
b. World Bank
c. International Program Center, U.S. Census Bureau
d. International Institute for Applied Systems Analysis

II. United States.
a. U.S. Census Bureau
b. Social Security Administration

III. European Countries
a. Eurostat
b. Federal Statistical Office of Germany
c. Statistics Netherlands
d. United Kingdom: Government Actuary's Department

IV. Other Developed Countries.
a. Statistics Canada
b. Japan: National Institute of Population and Social Security Research

AN OVERVIEW OF IMMIGRATION THEORY
a. Policy Framework
b. Neoclassical Framework
c. World Systems Framework
d. New Economics Framework
e. Social Network Framework
f. Dual Labor Market Framework

TOWARD BETTER PROJECTION PRACTICE.

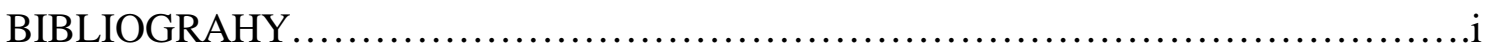




\section{INTRODUCTION}

In recent years, policy experts worldwide have come to understand the importance of demographic projections in their efforts to think strategically about long-term challenges, from national security to retirement security. Attention to these projections has in turn inspired a growing effort to study and improve the models, methodology, and assumptions that underlie them. Much progress has been made in improving the fertility and longevity modules of the demographic projection puzzle. Little progress, however, has been made in dealing with cross-border migration or (more specifically, from the point of view of most developed countries) immigration. A projection of population must rest, in part, on a projection of immigration. Yet most official immigration projections both in the United States and abroad continue to rely on ad-hoc assumptions based on little theory and virtually no definable methodology.

This lack of progress is a cause for concern. For roughly half a century, from the 1930 s to the 1980s, it was widely observed that immigration rates were at a historically low ebb. Even where rates were rising over time (in many developed countries after the early 1960s), it was widely believed that national policy could control them. Compared to the challenge of projecting fertility and longevity, therefore, the challenge of projecting immigration seemed unimportant and attracted little attention.

Now the tide has turned. Net immigration rates in most developed countries have recently surged, more than doubling in the United States and Western Europe as a whole since the 1960s and showing few signs of changing direction. One team of demographers, Mark J. Miller and Stephen Castles, claim the world is entering a new "Age of Migration" (Miller and Castles 1993). According to Douglas S. Massey, "In retrospect, it is clear that the end of the Cold War was a watershed event in the history of global migration, ending a policy regime that had held world migration rates at artificially low levels for more than forty years" (Massey 2003: 20). The upward surge has occurred, moreover, during a period in which both public opinion and immigration policy in most developed countries has grown increasingly restrictive. With undocumented or "illegal" entry growing faster than any other type of immigration, policy experts are no longer confident that total immigration is still subject to the effective control of national policy.

The range of plausible assumptions regarding long-term immigration rates is therefore widening. Unbounded by any consensus projection method, this widening range can now generate a similarly widening and often dramatic variety of long-term population outcomes. The spread between the "low" and "high" immigration variants for the U.S. Census Bureau projection for the national population in 2100 (U.S. Census Bureau 2000), for example, is 417 million - from a total of 438 million (low variant) to a 
total of 854 million (high variant). This is a very significant difference from almost any policy perspective. Indeed, the spread between the Census Bureau's low and high immigration assumptions has a larger impact on total U.S. population in 2100 than the spread between its low and high fertility and mortality assumptions combined.

Long-term immigration trends are attracting serious new attention from many official agencies. Given Europe's low fertility rate and the likelihood that immigration will make the difference between population growth or decline in many EU countries, Eurostat in 1994 began commissioning a series of research studies to improve understanding of the trends underlying immigration (Salt and Singleton 1995). In 2000, the United Nation's Population Division released Replacement Migration: Is It a Solution to Declining and Aging Populations? in an effort to assess the potential role of immigration in alleviating the fiscal and economic challenges facing many developed countries. In 2003, the Technical Panel on Assumptions and Methods of the U.S. Social Security Advisory Board conducted its first in-depth examination of the immigration assumptions in the long-term projections used by the Social Security trustees and made important recommendations.

The purpose of this survey is twofold: to assess where projection-making agencies stand in their practice of immigration projection and to explore how theoretical insights about immigration may help them improve projection practice. The first section (Inventory of Current Projection Practice) describes the current projection methods of leading national and international projection-making institutions worldwide. The second section (An Overview of Immigration Theory) scans the wide and varied array of "theoretical frameworks" which, thus far, have seldom if ever been incorporated into method. The third section (Toward Better Projection Practice) suggests some first steps to start harnessing theory and improving practice.

The focus of the survey is limited to long-term projection, that is, to projecting immigration beyond ten or fifteen years into the future. In recent years, policy experts have developed and refined many quantitative approaches to short-term immigration forecasts (e.g., by using time-series trends or by identifying business cycle correlations) that are not useful in the longer term. Near-term forecasts often depend critically on the accuracy of recent immigration data and the lagged impact of current policy (backlogged caseloads, family reunions, asylum events, etc.) — issues which are usually unique to each nation and each year. These issues are of less importance in longer-term projections.

When policy experts collect data on current or past immigration, they often take an interest in many types of information, from distributions by sex, age, and national origin to family status, educational level, and work experience. Efforts to project immigration are typically much less ambitious. In practice, most limit themselves to projecting total numbers: gross in-migration and out-migration or, in many cases, net immigration alone. A few also attempt to project changes in distribution by age and national origin. The scope of our inventory is limited to current practice. 
To better understand the survey's organization-and to anticipate some of its recurring themes-it helps to focus up front on four basic choices that confront any effort to develop or improve immigration projection methods.

The first choice is whether to constrain the projection method in any way to official national policy. This may not be an issue for academics and private-sector research organizations, but historically it has been a major consideration for the publicsector agencies that develop and publish most national immigration projections.

Simply put, governments do not like to announce likely futures that contradict current law or official policy objectives. It is no accident that until the 1980s, when rising illegal immigration forced policymakers to reconsider, nearly every national government simply equated projected immigration with current official policy. The trustees of the U.S. Social Security system did not consider "other-than-legal" immigration until 1988 (Social Security Administration 1997). Even today, it is hard for many governments to acknowledge behavior that deviates from law. Eurostat, in its 2002 survey of national projection methods in the European Union, reported that only one country (Portugal) admitted that "they made any allowance for illegal immigration in their forecasts" (Eurostat 2002b). The central scenario in Canada's official long-term projections continues to be "based on national policy" and makes no allowance for illegal immigrants (Statistics Canada 2001).

Most policy experts worldwide now argue that national policy should only be regarded as one variable among many when making projections - and a growing number of national governments appear to agree. Some seem to be taking illegal migration into account in their projections even if they do not say so publicly-and some are allowing for the possibility not just of immigration that violates current law, but of future changes in law itself. One key finding of the 2003 U.S. Social Security Technical Panel is the conclusion that "legislative limits regarding legal immigration, and their associated enforcement policies, are endogenous to broader social and economic processes, and thus may change in future years" (The 2003 Technical Panel: 31). Although it might seem obvious that projections extending decades into the future should accept the possibility of legislative change, it remains unclear how broadly the Social Security trustees are supposed to interpret their mandate to make projections based on "current law." Canada's position, interestingly, is that the possibility of future legislative change is reflected in its "high" and "low" projection variants.

Assuming a projection method is free from the constraint of official policy (and can allow for both future enforcement failure and policy change), the second basic choice is whether projections will be based on an explicit explanatory theory or model of immigration. Few if any long-term projections are. When describing how they make assumptions about future immigration, many agencies offer little more than a vague reference to "expert opinion"-_or else they say that their assumptions reflect "historical experience." But no assumption, even a "no change" assumption, can be turned into a projection without first confronting difficult methodological considerations. Does no change imply future immigration equal to the current year? Or the last decade average? Or the last fifty-year average? Does it mean an unchanged number or unchanged rate? If 
a rate, should it be a rate per capita or per employed person or per age group? Unchanged rates in the sending country as well as the receiving country? All projectionmaking agencies must deal with such questions. More often than not, however, the decision process takes place behind what Dennis A. Ahlburg and Wolfgang Lutz call a "veil of secrecy" (Ahlburg and Lutz 1998: 6).

Explanatory models or theories come in many types. Some rely at least in part on qualitative assessments of future trends. Others are strictly quantitative and rely on tested time-series models. Many, perhaps most, theoretical models are based on a presumed association between future immigration behavior and other future conditions that we believe can be projected with some confidence. Examples of such other conditions include multinational trends in population, wages and living standards, trade and capital flows, age distribution, education, urbanization, environmental change, and market orientation ("globalization"). A few models posit a causal link between conditions observable today (e.g., public attitudes toward immigration) and conditions in the future (e.g., immigration policy change, which in this theory is presumed to follow with a lag). What all models have in common is an explanatory argument that can be objectively evaluated and in some manner tested against historical evidence.

To the extent an agency chooses to ground its projections on a theory or model, it necessarily faces a third basic choice. How does it select among models? And if it relies on more than one, how does it weigh the relative importance of competing models? This choice is especially critical for immigration projections because there is such an abundant variety of immigration theories to choose from, many of them originating in very different academic disciplines (from economics and demography to sociology, political science, and comparative anthropology) that rarely speak to each other. Massey concludes, "At present, there is no single, coherent theory of international migration, only a fragmented set of theories that have developed largely in isolation from one another, sometimes but not always segmented by disciplinary boundaries" (Massey et al. 1993: 432). Even integrating the experiences of different nations can be difficult. According to Jeannette Money, the literature on immigration "tends to be country specific rather than comparative, making it difficult to sort between idiosyncratic factors and more generally applicable theories" (Money 1997: 686).

The new field of futures studies, which attempts to evaluate and improve methods of investigating the future (including the use of simulations, scenario-building, causal modeling, relevance trees, and cross-impact analysis) may offer some creative ways to distill disparate insights into a single projection method. Delphi, for example, is a formal and iterative process of survey and discussion often used in the private sector to bring large groups of experts toward a consensus estimate. Public-sector agencies seldom use such formal processes in developing demographic projection methods; indeed, even when they do explain why they arrive at a given method, which is rare enough, they almost never explain how they arrive at it. One conspicuous exception is the International Institute for Applied Systems Analysis (IIASA), which has developed a multi-stage "expert- and argument-based forecasting" process to assess the merits of theories ("arguments") offered by large panels of experts in arriving at the assumptions needed for demographic projection (Lutz ed. 1996 and Lutz et al. eds. 2004). Though its usefulness 
in sorting through different viewpoints on immigration trends has yet to be demonstrated, the process does seem promising.

A final choice confronting projection-making agencies is whether to assign any likelihood to their assumptions and outcomes. At present, few agencies formally incorporate probabilities into their projection methods. Instead, most create a range of scenarios or variants, each containing a "high" or "low" set of assumptions, and these variants mechanically generate single sets of outcomes. In effect, the traditional variant projection is simply a giant if-then proposition. In recent years, however, a growing number of experts have begun experimenting with probabilistic demographic projections (sometimes referred to as "forecasts"); and one agency, IIASA, uses an elaborate probabilistic method to generate likelihood values for all of its demographic outcomes, including global migration. Interest in this approach, whetted perhaps by the growing power of computers and statistical software, is clearly on the rise.

The argument in favor of the probabilistic approach is that it compels experts to assign likelihood weights at the assumption stage and then manages those weights properly through to the output stage. It also encourages experts to think through the simultaneous or lagged correlations among all of the projection variables-a task which, say supporters of the probabilistic method, enables them to avoid the sorts of logical inconsistencies that plague "variant" projections. (Example: Does it make sense to pair a low total fertility rate with a low immigration rate in the same "low variant" of a nation's long-term population projection?) Supporters of the traditional variant approach respond that not enough can be known about the probability distributions of long-term variables to quantify them. The probabilistic approach, they argue, adds a spurious precision that masks rather than clarifies the critical role played by the chosen assumptions. This caveat may be especially appropriate for immigration assumptions, since there remains such great uncertainly about how to project a central trend, much less about calculating the likelihood of deviating from that trend.

However projection-making agencies handle these four basic choices, they have thus far achieved little progress in developing an immigration projection method that most experts regard as even minimally reliable. As our inventory of current practice makes clear, few official projections use immigration assumptions that are justified by any explicit reference to a theory of how or why immigration happens. "[S]ince no single compelling theory of migration exists, projections are generally based on past trends and current policies" (O’Neill et al. 2001: 250). In this respect, immigration is regarded as uniquely disadvantaged among demographic assumptions. According to Lutz et al., "[I]t is more difficult to forecast future migratory streams than future trends in fertility and mortality" (Lutz et al. eds. 2004: 34). "Among the three major components of national population change...," concludes a recent report of the U.S. Census Bureau, "international migration is the component for which demographic science offers the least to future projections" (U.S. Census Bureau 2000: 15).

Yet if the main theme of the first part of this survey is how little progress has yet been made, the main theme of the second and third parts is how much progress might be achievable if the abundance of available explanatory insights about immigration could 
somehow be consolidated and harnessed. "A variety of theoretical models has been proposed to explain why international migration begins," writes Massey. Moreover, "...they cannot be assumed, a priori, to be incompatible" since they "conceptualize causal processes at such different levels of analysis - the individual, the household, the national, and the international" (Massey et al. 1993: 432-433). According to a recent Eurostat report, "By now, causes of international migration are well studied and there is more or less agreement with regard to the most important factors determining migration flows between countries. Relatively few attempts have been made, however, to link these theoretical considerations with empirical data" (Eurostat 2002a: 99). The implied message, perhaps, is that more such "attempts" should be made. The 2000 Committee on Population Projections report by the U.S. National Research Council offers similar grounds for optimism. Although "the limitations of migration projections are not easy to remedy" in the short term, it suggests, "a longer-term program of data collection and the appropriate use of theory to build dynamic models of migration may have some potential eventually to produce greater accuracy” (Bongaarts and Bulatao eds. 2000: 177-178).

Although experts would surely debate just how much ground there is for optimism, nearly all would agree that agencies can do better than they are now doing. Since demographic projections require some immigration assumption, abandoning the effort is in any case not an option. As Michael S. Teitelbaum puts it simply if enigmatically, "Projecting immigration is impossible, but unavoidable" (personal communication with authors). 


\section{INVENTORY OF CURRENT PROJECTION PRACTICE *}

The inventory of current projection practice presented here covers major international projection-making agencies, as well as national projection-making agencies in the United States and a selection of other developed countries. The focus is on longterm immigration assumptions-what they are, how they are derived, and how they are justified.

A few general observations will help orient the reader. Many agencies project net immigration directly without projecting its components: gross in-migration and gross outmigration. At least among the agencies included in the inventory, net immigration (with the minor and partial exception of Japan) is always projected as a level, as is in-migration whenever agencies project it separately. In contrast, emigration, when projected separately, is sometimes projected as a level, sometimes as a rate. In the latter case, it is usually assumed to be a fixed share of the "at risk population"- that is, a country's foreign-born stock.

There is considerable variation in how projection-making agencies handle current immigration policy. Most make at least some allowance for it, especially in the near term. A few explicitly build their projections around it - the case with Statistics Canada and the U.S. Social Security Administration. And a few, like the Federal Statistical Office of Germany, explicitly reject it as a useful guide to long-term (or even near-term) immigration trends. Spain's National Statistics Institute, contemplating the huge and unexpected surge in migration to Spain that began in the late 1990s, goes so far as to talk about the "inherent clandestine nature of immigration"

When projections are not based on current policy, they are generally based on "historical experience" or "expert opinion." Projection assumptions sometimes reflect judgments about how future demographic, economic, or political developments may affect long-term migration flows - and these judgments may in turn be informed by some explanatory theory of immigration. No agency, however, has attempted to incorporate these relationships into a dynamic long-term projection model.

A number of projection-making agencies assume that net immigration will remain constant throughout the projection period. Most of the rest assume that it will be constant once it reaches a "target" or "ultimate" level. Almost none-the U.S. Census Bureau is a notable exception-projects that net immigration levels will vary throughout the projection period. Most agencies publish high and low immigration variants that bracket their central or "best guess" variant. Although there is a rising interest in probabilistic forecasting among academic demographers, only two projection-making agencies included in this inventory (IIASA and Statistics Netherlands) take this approach.

\footnotetext{
* To avoid encumbering the text, references in this section are limited to special studies and direct quotations. Please see the "Projection Practice" section of the Bibliography for a complete (agency by agency) list of the sources consulted in preparing the inventory.
} 
As the inventory makes clear, there is a growing interest in developing better projection methods. Thus far, however, most of the attention has been focused on improving near-term projections - through better data collection, cross-country harmonization of definitions, time-series analysis of historical trends, and studies of past forecast errors. The process of setting long-term assumptions remains almost entirely ad hoc and judgmental.

\section{GLOBAL PROJECTIONS}

We begin the inventory by reviewing immigration projection methods at the major agencies producing global population projections. There are four: The United Nations, the World Bank, the International Program Center at the U.S. Census Bureau, and the International Institute for Applied Systems Analysis in Austria. Global population projections, and especially global immigration projections, must overcome enormous data and definitional hurdles. Projection-making agencies therefore make simplifying assumptions. They usually project net migration rather than its components - and until recently, they often ignored immigration altogether.

\section{a. United Nations Population Division}

The United Nations Population Division produces the most widely cited set of global population projections. The projections, which are published in its World Population Prospects series, are revised every two years. The latest 2002 Revision provides projections of the world's population by country through 2050 . Periodically, the UN also pub lishes longer-term projections that extend its regular projection series. In 2004, it released a special set of projections through the year 2300.

In developing immigration assumptions, the UN begins by looking at "recent" experience, a timeframe that may vary considerably depending on data availability. In some countries, it projects that net immigration will continue throughout the projection period at close to its recent average. In other countries, where recent experience is deemed to be unusual, net immigration is trended from its current level to an ultimate level that is generally reached within ten to twenty years. The UN makes these ad hoc adjustments in consultation with experts from national projection-making agencies. Countries that have recently sent or received large numbers of refugees constitute a special case. The UN projects that refugees will return to their home country within five to ten years, after which net immigration is assumed to return to zero-unless of course the country in question is a traditional sending or receiving country.

Although the UN has been making population projections since the 1950s, it has only recently begun to pay much attention to projecting international migration. For many years, the UN assumed that net immigration in most countries would be zeropartly because immigration is "less amenable to being reliably projected" than other demographic variables (UN Statistics Division 2004), partly because, so long as fertility remained high, leaving it out didn't have much effect on population growth rates in most 
countries. As recently as its 1998 Revision, the UN projected that net immigration would be zero in 50 countries throughout the projection period; in 103 others, it assumed that net immigration would rise or fall to zero during the period. Even today in its special long-term projections, the UN makes the radically simplifying assumption that, beyond 2050, all international migration ceases.

\section{b. World Bank}

The World Bank has prepared global population projections since 1978. The projections are updated annually and published in the Bank's World Development Indicators CD-ROM. The latest projections cover the period 2000-2045.

Unlike the UN, the World Bank makes no attempt to make "best guesses" about country-specific trends in international migration. It assumes that net immigration in every country will steadily rise or fall until it reaches zero. Zero net immigration is attained in most countries by the 2030s and everywhere by the 2040s, including traditional sending and receiving countries like Mexico and the United States. The World Bank's published descriptions of its projections offer no rationale for its immigration scenario. A number of projection-making agencies, however, including the UN and the U.S. Census Bureau, calculate illustrative zero net migration scenarios in order to highlight the impact of natural increase on population growth. The purpose of the World Bank scenario is presumably analogous. In any case, it cannot be interpreted as a realistic projection of future trends in international migration.

\section{c. International Program Center, U. S. Census Bureau}

Many readers will be unaware that the U.S. Census Bureau is a major resource on world population trends. The International Program Center (IPC) at the Bureau maintains a large global database of demographic and socio-economic indicators. It has also published global population projections biannually since 1985 in its Global Population Profile series. The latest projections were released in 2004 and cover the period 2002 to 2050.

IPC divides countries into two main groups based on the importance of international migration in their history. If past migration has had a negligible impact on a country's population growth, future net immigration is assumed to be zero. For countries with a history of significant migration, the level of net immigration over some recent period is usually held constant for the "near future." The published description of the current projections does not offer any detail on how this near-term level is calculated or how net immigration is assumed to change over the longer-term future. In previous projections, however, the IPC usually assumed that it would eventually become zero. Like the UN, the IPC treats countries that have recently experienced large refugee flows as a special case. Refugees are assumed to return to their countries of origin over the next five to ten years, after which net immigration returns to zero. 


\section{d. International Institute for Applied Systems Analysis}

The International Institute for Applied Systems Analysis (IIASA) is a nongovernmental research organization located in Austria that conducts interdisciplinary research on a wide range of policy issues. The World Population Program at IIASA began producing global population projections in 1994 and has subsequently updated them in 1996 and 2001. The 2001 revision, which was released in final form in 2004, covers the period 2000 to 2100 . IIASA projects the population for thirteen major regions of the world rather than for individual countries. "By doing so," it explains, "much of the world's heterogeneity is taken into account, and we need not bother with national particularities, especially with respect to migration" (IIASA 2004). The United States and Canada together constitute the North American region.

To arrive at its projection assumptions, including its immigration assumptions, IIASA uses a version of the Delphi method it terms "expert- and argument-based forecasting." A panel of "resource" experts is called on to develop high and low assumption values. The experts are instructed to choose values that define a 90 percent confidence interval, meaning that only 5 percent of all possible cases should lie above and 5 percent below the range. The y are also instructed to supply "arguments" in support of the values they select. The input of the resource experts is then reviewed by "implementation" experts, who select the final projection assumptions. For North America, the low net immigration assumption is zero and the high net immigration assumption is 2 million.

The assumptions are then used to generate 2,000 stochastic projection runs. Whereas most projection- making agencies use high and low variants or scenarios to bracket a plausible range of outcomes, IIASA explicitly tries to quantify the uncertainties involved in its population projections. The actual assumption paths underlying the individual projection runs are derived randomly from the assumptions' uncertainty distribution. The projection output is thus probabilistic. According to the 2001 IIASA projections, for instance, there is a 95 percent probability that the population of North America in 2050 will be between 329 million and 536 million, while the median projection value is 422 million. Although IIASA pioneered this method, a number of academic demographers and at least one public-sector agency—Statistics Netherlandsnow make probabilistic population forecasts as well.

\section{UNITED STATES}

There are two major projection-making agencies in the United States: the U.S. Census Bureau and the Social Security Administration (SSA). Other agencies concerned with population trends use the projections published by one or the other. The Bureau of Labor Statistics' labor-force projections, for instance, are based on the Census Bureau middle series, while the Congressional Budget Office and Office of Management and Budget use SSA's long-term demographic scenarios. The Department of Homeland 
Security, which includes the former Immigration and Naturalization Service, does not make immigration projections.

\section{a. U.S. Census Bureau}

The Census Bureau is the primary U.S. government agency responsible for making population projections. It projects the population of the individual states through 2025 and of the nation as a whole through 2100. In addition to projecting the population by age and sex, the Census Bureau also projects it by race and Hispanic origin. The latest complete set of national population projections was released in 2000 and covers the period 1999-2100. A new set of interim projections based on 2000 Census data was released in 2004 . We discuss the 2000 projections, however, since the summary numbers available for the interim projections do not include any detail on projected immigration levels and since the immigration projection method remains unchanged.

The 2000 projections, by contrast, embodied a major shift in the Census Bureau's immigration projection methods. Prior to 2000, future levels of immigration and emigration were based on recent historical averages and assumed to remain constant throughout the projection period. In the 2000 projections, the Census Bureau takes a new approach. It now assumes that immigration policies and levels will change in response to future developments. "While it may be acceptable in the near term to view migration as a consequence of existing immigration law and policy, this assumption loses merit in the longer term" (U.S. Census Bureau 2000: 16). Moreover, it explicitly models one longterm development - the aging of the U.S. population - that can be expected to have an impact on migration flows.

The Census Bureau anticipates that the aging of the U.S. population will increase immigration "pull" beginning in the 2010s. As old-age dependency ratios rise and growth in the working-age population slows during the Baby Boom's retirement, immigration levels are projected to increase substantially. Although other projectionmaking agencies around the world sometimes consider future demographic developments in setting long-term immigration assumptions, the Census Bureau appears to be unique in building a demographic "feedback" into the projections itself.

Demographic shifts in sending countries may also affect future levels of immigration to the United States. The Census Bureau makes no attempt to model the potential impact, plus or minus, of population aging in sending countries on total U.S. immigration. It does, however, assume that population developments abroad will affect the composition of migrant flows. Over time, the Census Bureau projects that relatively fewer immigrants will come from Latin America, where decelerating population growth is expected to ease immigration "push"-while relatively more will come from younger and faster-growing countries in Africa, the Middle East, and South Asia. The Census Bureau does not discuss the policy implications of this shift. Implicitly, however, its projections seem to assume that U.S. immigration policy, which is mainly based on family reunification, will change to allow new sending countries to substitute for old ones. 
The Census Bureau projections anticipate a somewhat roller-coaster path for U.S. immigration. Net immigration is initially assumed to fall from some 950,000 in 1999 to 700,000 in 2010, as the surge in family reunification immigration triggered by the Immigration Reform and Control Act of 1986 finally subsides. It then rises sharply to 1.1 million in 2030 as the demographic feedback kicks in. Thereafter, it declines again-not because in-migration is projected to decline, but because out-migration is projected to rise. This is the result of another change in projection methods. Beginning with the 2000 projections, the Census Bureau projects emigration not as a level, but as a percentage of the stock of foreign-born residents of the United States. This means that higher immigration ultimately leads to higher emigration as well.

In addition to its middle series, the Census Bureau also publishes low and high immigration variants which it describes as "reasonable maximum and minimum values." Under the low variant, net immigration drops to 113,000 by 2100 , while under the high variant it rises to 3 million. As noted earlier, this enormous spread in immigration assumptions yields an equally enormous spread in projected U.S. population totals: from 438 million in 2100 under the low variant to 854 million under the high variant. As the Bureau explains, "The margin of uncertainty around the middle-level assumption is, of necessity, relatively wider for international migration than for births or deaths" (U.S. Census Bureau 2000: 19).

\section{b. Social Security Administration}

The US Social Security Administration's (SSA) Office of the Actuary prepares its own long-term (75-year) population projections each year. The projections underlie the cost scenarios that the Social Security trustees use to evaluate the system's finances. The Office of the Actuary currently prepares three sets of population projections and three cost scenarios: the low-cost, the intermediate, and the high-cost. High immigration is part of the low-cost scenario, while low immigration is part of the high-cost.

In contrast to the Census Bureau, SSA assumes that immigration will remain constant over the long run. Current immigration levels are trended toward ultimate levels, which, once reached, are maintained throughout the rest of the projection period. In the 2004 intermediate scenario, net immigration is projected to attain its ultimate level of 900,000 in 2024. The ultimate levels for the high-cost and low-cost scenarios are 672,500 and 1,300,000, respectively. The ultimate immigration level in SSA's intermediate scenario is close to the average immigration level in the Census Bureau's middle series. The range between SSA's high-cost and low-cost scenarios, however, is much narrower than the range between the Census Bureau variants.

This narrower range is explained by SSA's current-policy projection framework. According to the Office of the Actuary, the intermediate scenario assumption represents its "best guess" of future current-law immigration levels, while the low-cost and highcost scenario assumptions represent upper and lower bounds. The projections include estimates of immigrants admitted under the flexible caps for the family-based, employment-based, and diversity categories of the Immigration Act of 1990, as well as estimates of asylum-seekers and refugees. Although it is not entirely clear that it is 
consistent with its current-policy framework, SSA also takes illegal immigration into account. Since 1988, its projections have included estimates of net "other than legal" immigration, which the Office of the Actuary assumes will continue at substantial levels throughout the projection period (the ultimate assumption in the intermediate scenario is $300,000)$.

SSA's projections are periodically reviewed by an official Technical Panel on Assumptions and Methods. Traditionally, technical panels have passed over SSA's immigration assumptions with barely a mention. The most recent 2003 Panel, however, devoted considerable attention to the subject. In its report, it concluded that SSA underestimates likely future levels of net immigration. The reason, according to the Panel, is that SSA's current-policy, fixed-number projection framework implies that immigration will steadily shrink in importance in future years relative to the size of the growing U.S. population and economy. "In light of the sustained, rapid increase of net migration over more than five decades, the Panel finds this assumption to be highly implausible" (The 2003 Technical Panel: 26). The Panel goes on to recommend that SSA abandon the fixed-number framework and instead project immigration as a rate.

The Technical Panel actually raises two entirely distinct questions - first, whether SSA's net immigration assumption is too low, and second, whether there is any necessary correlation between immigration and population growth. Neither question has an obvious answer. Regarding the first, the Panel itself acknowledges that future demographic, economic, and policy developments could exert countervailing pressures. The aging of the U.S. population may increase immigration pull. Then again, the aging of Mexico's could reduce immigration push. And while it is true that immigration to the United States rose dramatically over the postwar era, much of the rise was simply a recovery from the unusually low levels of the Great Depression and World War II.

As for the rate recommendation, it's worth recalling that no major projectionmaking agency uses this method. Doing so would first require settling some thorny methodological issues. Even accepting the Technical Panel's premise that over the long run the size of net immigration will rise along with the size of the population, it is not immediately apparent which population is the relevant one-the working-age population or the total population, the population of the receiving country or that of the sending country. Nor is it apparent what time period should be considered in determining the rate assumption-recent experience, long-term experience, or something in between The Technical Panel does not really address these issues. It simply assumes that the relevant population is the total U.S. population and that the relevant historical average is the longest feasible historical average, which turns out to be 1821-2002. In the end, this may be no less simplistic than blindly projecting current law.

\section{EUROPEAN COUNTRIES}

Twenty-five years ago, net immigration was a relatively inconsequential component of population growth in most European countries. Today, it accounts for over 
three-quarters of the total annual population increase in the EU15. Not surprisingly, national projection-making agencies are paying closer attention to immigration-as is Eurostat, the European Union's statistical unit. The first set of Eurostat population projections, released in the early 1980s, ignored international migration entirely, while the second set, released in the mid-1980s, ignored it in all counties except Germany and Ireland, where it loomed particularly large. Beginning in the 1990s, however, Eurostat projections have included immigration for all EU member states.

Despite the new attention, projection methods mostly remain rudimentary. According to a 2002 Eurostat survey, roughly half of all countries base their immigration assumptions exclusively on "expert opinion" (Eurostat 2002b). Although a growing number of projection-making agencies employ time-series analysis and other statistical techniques to analyze (and sometimes extrapolate) historical trends, none has developed a long-term projection model based on an overall theory of immigration. Some simply project that immigration will remain constant at or near some recent historical average. Most of the rest trend it to a target or ultimate level typically reached early in the projection period.

The inventory looks at Eurostat's latest projections, as well as the latest projections of three EU countries: Germany, the Netherlands, and the United Kingdom. All are significant immigration countries_-and all are paying increasing attention to projection method.

\section{$\underline{\text { a. Eurostat }}$}

Eurostat publishes internationally consistent population projections for the EU countries roughly every five years. The latest set of projections was released in 2000 and covers the period 1998-2050. In the past, Eurostat outsourced much of its projection work to other agencies, including Statistics Netherlands, the Netherlands Interdisciplinary Demographic Institute, the Netherlands Economic Institute, and the Migration Research Unit of University College London. The next set of projections, which is due out in the fall of 2004, is for the first time being prepared internally.

Of all the projection-making agencies in this inventory, none has devoted more effort to studying immigration projection method than Eurostat. In the mid-1990s, it launched a major research program called "International Migration by Major Groups" designed to develop improved models for forecasting immigration. The focus of the research, however, has been exclusively near term. Most of the modeling aims to clarify "the correspondence between the economic business cycle and international migration" (Eurostat 2003: 121). This work has produced some valuable insights. It turns out, for instance, that there is a strong negative correlation between immigration rates and unemployment rates in countries like Germany and the UK, where much immigration is labor-market motivated, whereas there is no such correlation in countries like France, where it isn't. Little of the work, however, has much relevance for projecting long-term immigration trends - and indeed, Eurostat's long-term projections resemble those of most national agencies. 
The latest Eurostat projections include three immigration variants. According to Eurostat, the main or central variant is based directly on historical experience. Total net immigration to the EU15 is assumed to reach a target level of 622,000 in 2010, which Eurostat notes is roughly the average for the 1980s and 1990s. After 2010, net immigration is assumed to remain constant. As Eurostat explains, "It is believed that it is nearly impossible to make realistic assumptions on developments in migration after 2010" (Eurostat 2001b: 36). According to Eurostat, its variant projections are based on "internally consistent" economic and policy scenarios. But as it turns out, Eurostat's low and high immigration assumptions - 311,000 and 933,000 from 2010 onward-are simply set 50 percent lower and higher than the baseline assumption. The scenarios merely provide a justification for the assumptions, which are themselves arbitrarily chosen.

According to Eurostat, the new 2004 projections will be based on an entirely new projection method. Nothing has yet been published describing the method, however, and it remains unclear how it will handle the long-term projection challenge.

\section{b. Federal Statistical Office of Germany}

The Federal Statistical Office of Germany has been preparing national population projections for roughly forty years. The tenth and most recent set of projections, which was published in 2003, covers the period 2002-2050.

The Federal Statistical Office publishes three immigration variants (low, medium, and high) and tracks two categories of migrants (ethnic German and non-German). In all of the variants, net immigration of ethnic Germans is assumed to decline steadily and eventually fall to zero as the reserve of potential immigrants in the countries of Central and Eastern Europe is exhausted. In the medium variant, non-German net immigration is assumed to be a constant 200,000 per year throughout the projection period, roughly its average over the past fifty years. The corresponding assumptions in the low and high variants are 100,000 and 300,000.

Except for the distinction between ethnic Germans and non-Germans, there is little remarkable about the Federal Statistical Office's projection method, which resembles that of Eurostat and many other national agencies in Europe. What's perhaps more unusual is the candor with which basic assumption choices are discussed.

The Federal Statistical Office rejects current immigration policy as a basis for projection. One reason is that in the past Germany has witnessed huge fluctuations in immigration within the span of just a few years as economic and political circumstances have changed, and along with them immigration policies. Net immigration of nonGermans rose to nearly 600,000 during the late 1960s and early 1970s as waves of "guest workers" flooded into Germany, only to fall to minus 200,000 by the mid-1970s as Germany's postwar economic miracle stalled. It once more soared to 600,000 in the late 1980 s and early 1990s, this time driven by waves of refugees and asylum-seekers, only to plummet again and turn negative in the late 1990s. 
More fundamentally, the Federal Statistical Office believes that over the long run immigration is determined by broad demographic and economic developments that may lie beyond the ability of governments to control. The Statistical Office sums it up this way: "The balance [net immigration] depends firstly on the migration potential, which is determined in turn by political, economic, demographic or indeed ecological developments in the countries of origin. Secondly, it is influenced by migration policies in Germany, by the situation of the German labor market and by the economic and social attraction of Germany as a destination country" (Federal Statistical Office of Germany 2003: 21).

\section{c. Statistics Netherlands}

Statistics Netherlands has been producing the official population projections for the Netherlands since the early 1950s. It currently publishes long-term projections every other year. The latest set was released in 2003 and covers the period 2002-2050. Like IIASA, Statistics Netherlands makes probabilistic projections.

Statistics Netherlands' projection methods are among the most technically sophisticated in use today. It separately projects immigration and emigration for migrant groups from twelve different countries or regions, all of which have their own probability distributions. Like a growing number of agencies, Statistics Netherlands projects emigration as a share of the foreign-born population stock - or in this case, stocks. But it also goes a step further. Not only does it track the size of twelve different foreign-born populations, it also tracks their "vintage." Its assumption is that the longer immigrants have lived in the Netherlands the less likely they are to leave again.

Yet ultimately, the quality of the projections depends on the quality of the assumption inputs. And here Statistics Netherlands, like most projection-making agencies, simply relies on expert opinion. The process is more institutionalized in the Netherlands than it generally is elsewhere. A special Advisory Commission for Population Projections was established in 1975 to provide guidance in developing fertility, mortality, and migration assumptions. Statistics Netherlands also regularly consults with the Netherlands Interdisciplinary Demographic Institute, one of Europe's preeminent population research institutes. But whatever the process, the projection assumptions - and the probability distributions they generate-remain largely judgmental.

\section{d. United Kingdom: Government Actuary's Department}

The UK population projections are published every two years by the Government Actuary's Department (GAD). The latest complete projections were issued in 2004 and cover the period 2002-2072. There are separate projections for the United Kingdom as a whole, as well as for its constituent parts: England, Scotland, Wales, and Northern Ireland.

GAD's projection method is somewhat unusual. Whereas most agencies base their immigration assumptions on historical averages, GAD begins by extrapolating the 
past decade's historical trend a decade into the future. It then averages the extrapolated values. The result-130,000 in the latest projections-becomes the immigration assumption used in GAD's baseline scenario. GAD also calculates high and low variants, whose assumptions are set roughly 50 percent higher and lower than the baseline assumption. According to GAD, the variants are not meant to indicate "extremes," but merely to illustrate what the future might look like if net immigration is significantly higher or lower than in its central projection.

The UK is now experiencing record levels of net immigration. As recently as the mid-1980s, it was still a sending country. Since then, however, net immigration has surged. In no year in the UK's history before 1998 did net immigration ever exceed 100,000 . Yet GAD assumes that in the future it will indefinitely average 130,000. GAD neither discusses the causes of today's immigration surge nor explains why it thinks today's higher levels will continue. Indeed, it offers no discussion of the factors driving immigration at all. Its projection method-which interestingly was developed in the early 1990s when immigration was still low-appears to be purely mechanical.

\section{OTHER DEVELOPED COUNTRIES}

The remaining group in the inventory includes two countries: Canada, a traditional receiving country, and Japan, a country where immigration, though historically unimportant, is now for the first time the focus of growing policy attention.

\section{a. Statistics Canada}

The Canadian population projections are prepared by Statistics Canada. The most recent projections, which were released in 2001, cover the period 2000-2026 at the provincial and territorial level and 2000-2051 at the national level.

Statistics Canada explicitly bases the immigration assumption in its central or medium variant projection on current policy. It assumes that (gross) migration will remain constant throughout the projection period at 225,000, which is the upper value of the government's official 1999 immigration target for the year 2000. Unlike the U.S. Social Security Administration's "current policy" framework, Statistics Canada's makes no allowance for illegal immigration. According to Statistics Canada, the underlying premise of its approach is that "immigration assumptions tend to be more accurate when based on policy decisions taken by the government, than when based solely on the statistical analysis of past trends" (Statistics Canada 2001: 1).

Statistics Canada publishes projection variants that take into account the possibility that future immigration levels will be affected by "socio-economic and political conditions, both within and outside Canada" (Statistics Canada 2001: 1, 3-4). Interestingly, however, it justifies these variant projections as alternative policy scenarios. The high variant assumption $(270,000)$ reflects "a convergence of economic, humanitarian, and demographic factors [that] could lead to a policy of continuing high immigration," while the low variant assumption $(180,000)$ "reflects a possible downward 
revision of future immigration levels." Given the steady increase in immigration since the mid-1980s - and the potential impact of Canada's aging on future immigration pullStatistics Canada believes that the high variant represents the more plausible scenario.

\section{b. Japan: National Institute of Population and Social Security Research}

The National Institute of Population and Social Security Re search (IPSS) prepares the official Japanese population projections. The projections are published every five years following Japan's quinquennial Census. The most recent projections were released in 2002 and cover the period 2001-2100.

Similarly to Germany, Japan makes separate projections of ethnic Japanese and non-Japanese immigration. It assumes that net ethnic Japanese immigration will continue at its recent (1995-2000) average annual rate. Its projections of net "foreign" immigration are based on an extrapolation of the historical trend since 1970, at least in the near to medium term. Net foreign immigration rises sharply over the first two decades of the projection period, before flattening out at roughly 100,000 per year from the 2020s onward.

This method represents an important change from earlier practice. In previous projections, IPSS assumed that net foreign immigration (like net ethnic Japanese immigration) would remain constant at its recent historical average. In the 1997 projections, the average used was 1990-1995, which turned out to represent an unusual and short-lived downturn in what had for the prior two decades been a generally rising historical trend. The new method was developed in recognition that near-term averages are a problematic basis for long-term projections. What makes it unusual is that projections are based on long-term historical trends rather than the long-term historical averages. 


\section{AN OVERVIEW OF IMMIGRATION THEORY}

The poverty of explanatory models in the current practice of immigration projection contrasts sharply with the abundance of theories proposed and discussed by experts in a variety of social science and policy disciplines. Here we attempt to outline the broad theoretical frameworks which, with effort and research, could help serve to improve projection practice. We identify six such frameworks, each having its own unique history and literature: the policy, the neoclassical, the world systems, the new economics, the social network, and the dual labor market frameworks.

There are many ways to understand how these six frameworks approach migration. One way is to distinguish explanations in terms of push factors versus pull factors. Push factors, which create migration pressure within a sending country or region, range from poverty and unemployment (labor migrants) to political turmoil (refugees). Pull factors are generated by the attractiveness of the receiving country and give a direction to migration flows. The neoclassical framework, since it derives from a supply and demand analysis of economic and demographic conditions in both sending and receiving countries, encompasses both push and pull factors in equal measure. Other frameworks tend to lean in practice more toward one or the other. The world systems and new economics frameworks tend to lean more toward push explanations. The policy and dual labor market frameworks tend to lean the other way, toward pull explanations.

A second way to distinguish explanations is in terms of quantitative versus qualitative models. Here there is a spectrum: At one end, the neoclassical framework describes a body of theory that (along with accompanying statistical tests) is almost entirely quantitative. The new economics and dual labor market frameworks are occasionally quantitative. The others are almost entirely qualitative. A similar spectrum distinguishes frameworks whose method stresses individual incentives, rational choice, and markets from those whose method stresses social forces, community or cultural values, and history.

A third way to sort the frameworks is by whether they tend to argue, most of the time, for a long-term rising or falling trend in global migration. The neoclassical framework tends to point to long-term stability or decline. Migration pressure should ease over time as the demographics and living standards of sending and receiving countries converge. The policy framework could lean either way, but again suggests that decline is a real possibility by its attention to public attitudes, which in recent decades have in many receiving countries turned against immigration. The remaining frameworks, on the other hand, tend to suggest that a secular rise in migration rates will continue indefinitely, along with modernization and globalization. Massey, who probably belongs in the "social network" camp, sums up this view as follows, "Current theoretical and empirical knowledge... suggests that, if anything, migratory flows will grow throughout the world" (Massey 1999: 318). 


\section{a. Policy Framework}

For many generations, the supposed efficacy of national immigration policy deterred most social science experts from taking much interest in immigration projection. If nation states could control migration at will according to the public interest, the whole question of how to explain it and project it was largely swept off the table. Over the last generation, however, the global rise of illegal immigration amid heated new policy debates over immigration restrictions has persuaded many experts to take a fresh interest in the role of public policy. Many social scientists are looking empirically for the first time at how policy design and enforcement affect real-world immigration incentives and change immigration behavior (e.g., Cornelius 1989, Espenshade 1990, 1994). They sometimes come to the counterintuitive finding that stricter enforcement can actually boost immigration.

Political scientists and sociologists are also investigating how overall policies and laws change over time (e.g., Cornelius et al. 2004 and Money 1999). How do interest groups and voters at large determine the direction of policy? Why, in some eras, do laws become more permissive or more restrictive than in other eras? When do legislators in democratic nations have a genuine incentive to limit immigration, and when is their goal rather to engage in "symbolic" measures to appease opinion? By studying voter surveys and legislative patterns, some of these experts are formulating models in which the very direction of national policy is endogenous ly determined by other assumed social, demographic, or geopolitical trends.

\section{b. Neoclassical Framework}

By far the oldest and most venerable perspective, with origins going all the way back to classical political economy in the early nineteenth century, the neoclassical framework is inspired by a longstanding observation: Large migration streams tend to move from poor countries in which the youthful population is outstripping capital and land to rich countries in which the opposite is true. The insight of neoclassical theory is that there is a global labor market and that migrants will move from low-wage countries to high-wage countries if and when the wage differential is larger than the costs of moving. There are many obvious historical examples, from the mass migration of southern and eastern Europeans to the United States in the late nineteenth and early twentieth centuries to the "Great Migration" of African Americans from the rural south to the industrial north in the early to mid-twentieth century. The famous "Laws of Migration" promulgated by Ernest G. Ravenstein in 1885 were largely based on marketplace incentives. In 1932, John R. Hicks offered perhaps the best-known formulation of the neoclassical framework: "Differences in net economic advantages, chiefly advantages in wages, are the main causes of migration" (Hicks 1932: 76).

Since the 1950s, the neoclassical framework has given birth to a vast academic literature in which migrant behavior is described by marketplace and optimization models of increasing sophistication (e.g., Lewis 1954, Todaro 1969, and Borjas 1987). The framework has been appealing because it formally takes into account both push (supply) 
and pull (demand). It has been especially attractive to most economists and many demographers because it is the most quantifiable and projectable. Though still dominant, the neoclassical framework has come under increasing attack in recent decades for its unrealistic "ideal market" assumptions and its disinterest in the role of culture and social ties (except perhaps as an "adjustment cost"). Other theories have been developed largely in reaction-to offer a more complete view that can explain major trends that neoclassical theory alone cannot.

\section{c. World Systems Framework}

The basic observation of the world systems theorists is that migration rarely comes from the very poorest parts of the world, which is what neoclassical theory would suggest. Why? According to the world systems framework, immigration only happens after societies have been incorporated into the capitalist world market. Peoples in very traditional societies (however poor) rarely migrate. Only after a society has been globalized and marketized, and after all of the social and cultural dislocations that accompany this process, do people begin to pick up and move in response to their perceived "relative deprivation." The resulting migration flows are often directed toward countries to which ties were established during their "colonial" expansion phase. Pakistanis and Indians, for example, traditionally migrate to the United Kingdom, Algerians to France, Indonesians to the Netherlands, Filipinos to the United States. Based on the historico-structuralist approach of Immanuel Wallerstein (1974) and on earlier Marxist critiques of imperialism, the world systems view maintains that immigration is part of a unidirectional global evolution in which "periphery" economies generally do not replicate the success of "lead" economies. It does not share the optimistic functionalism of the neoclassical school.

Most recent work from this perspective (e.g., Sassen 1988 and Portes and Rumbaut 1996) looks closely at the attitude shifts that give rise to global migration and the institutions and locales that sustain it (e.g., the well-known "world city hypothesis" described in Friedmann 1986). Many world systems theorists believe that, once set in motion, the movement of migrants from poor and traditional societies to rich and modern societies - and the movement of remittances and visits in the other direction - will further marketize the sending country, thus accelerating immigration. This is called "cumulative causation," an idea first developed by Gunnar Myrdal in 1957 and further elaborated by Massey in 1990. Migrants send remittances home and raise the living standard of family members who stayed behind. The rest of the community experiences further relative deprivation, increasing the likelihood they will migrate themselves. Of all frameworks, the world system perspective comes closest to encompassing what most experts mean by the general term "globalization."

\section{d. New Economics Framework}

The new economics framework begins with another widespread observation that seems anomalous from the neoclassical perspective. Most migrants do not consist of 
entire families who make one-time permanent moves to a new country. Rather, most consist of family subgroups who spend many years moving back and forth from the "old" to the "new" country. New economics theorists therefore reject the assumption that migration is a single decision made by a single individual or family head. They instead urge a model that treats migration as a series of decisions made within the context of intrafamily relationships. Families send members abroad not just to maximize income in the form of remittances, but to diversify income and insure against risk. According to new economics theory, the wage differential bears only a weak and secondary link to migration behavior-and economic development in the sending countries may thus not do much to reduce migration.

Like many other challengers to the neoclassical orthodoxy, the new economics framework first arose in the early 1980s and has been gaining attention ever since (e.g., Stark and Bloom 1985 and Taylor 1999). More than world systems theory, it is willing to employ conventional economics to identify specific causes of market failure, such as the inability of villagers in many developing countries to buy insurance or change occupations. The new economist theorists emphasize the large size and historical importance of cross-border remittance flows - from Irish men in America to families back home in the 1850s, for example, or from Filipino women in America to families back home in the 1990s. They were among the first to identify the potential problem of "brain drains" from sending countries; they were also among the first to focus on patterns of intrafamily ties and travel, research that pioneered the way for social network theory.

\section{e. Social Network Framework}

If neoclassic al theory is correct, even as amended by the further insights outlined above, migration should be a widely diffuse phenomenon, involving randomly scattered families throughout sending countries and randomly scattered destination cities throughout receiving countries. In fact, migration almost never happens this way. A major "wave" of migration typically originates among large numbers of people from a small number of sending communities - and ends in an equally small number of receiving locations. Why? Because, argue social network theorists, the existence of kin and other social networks in both sending and receiving countries makes immigration less costly, less dangerous, and less uncertain. Networks reduce the risks and increase the returns of migration. Relatives and friends help new immigrants find jobs. They also provide social and cultural support in an immigrant community with a familiar language, food, religion, and customs. Network theorists (e.g., Hugo 1981 and Gurak and Caces 1992) try to explain how all this works. Some of them (e.g., Massey and Zenteto 1999) have combined networks and "social capital" theory to generate models of migration.

According to the social network framework, immigration is a highly "path dependent" phenomenon: The choices made by a few early pioneer immigrants often determine the direction of the floodtide that follows. Yet if immigration is hard to get started, this framework also suggests that it is hard to stop, since networks tend to create immigration momentum. Migration may continue even if, in the neoclassical view, there wouldn't be sufficient reason for it to start in the first place. During the late 1990s, for 
example, Mexican immigration to the United States accelerated despite large improvements in the Mexican economy during those years. Network-induced momentum may explain why governments find it easier to prevent immigration in the first place than to shut it off once it is underway. This momentum may also mean that government policies that favor family reunification, by helping to strengthen and perpetuate networks, directly undermine efforts to discourage a larger flow.

\section{f. Dual Labor Market Framework}

In its essentials, the neoclassical framework posits a global labor market in which migrants (as labor) respond to global market signals very much like any other mobile factor of production (e.g., capital). Yet even allowing for imperfect information and the high cost of communication and transportation, such global labor markets are far from perfect. One conspicuous imperfection is that, in most countries having large immigrant stocks, certain low-wage job categories become associated with immigrant job holders and thus are no longer considered by large numbers of potential nonimmigrant workers. In effect, a social class stigma segments the national labor market into two parts. The dual labor market framework (applied originally to different social classes) goes back in England to John Stuart Mill and in America to the institutionalist economists of the early twentieth century. Its specific application to immigrant labor is much more recent (e.g., Piore 1979 and Dickens and Lang 1988).

Dual labor market theorists often see themselves as providing a "demand-side" perspective on the world systems dynamic of expanding capitalism and globalization. They point out that, once it begins, the segmentation of labor markets can quickly become self-reinforcing. As potential native workers leave the immigrant job definitions, wages do not fall as far as they otherwise might in the presence of immigration. This encourages more immigration. Furthermore, the same ethnic or cultural attributes of certain jobs that work to discourage native job seekers may further encourage immigrant job seekers who may be reassured by the familiar setting of their new employment (especially within so-called "enclave communities"). There is a long-standing debate among economists over the basic wage-segmentation premise of the dual labor market framework, or at least its practical importance. Yet few would quarrel with their key insight, which is that people's employment choices are often determined, in part, by considerations of class solidarity and cultural familiarity. 


\section{TOWARD BETTER PROJECTION PRACTICE}

This survey has revealed that there is an enormous chasm between the rudimentary state of immigration projection practice and the explanatory richness of immigration theory. What continues to hinder advances in practice are not just the limitations of projection method and agenc y resources, but a widespread pessimism about the very possibility of improvement. Most agencies focus much of their attention on the near term-and in the near term, immigration is undeniably volatile and difficult to predict. Unexpected movements of refugees and asylum-seekers, not to mention erratic vagaries of the business cycle and geopolitical events, can trigger dramatic year-to-year oscillations in net immigration. One might reasonably conclude that if the near term is so difficult, the long term must be just about impossible.

But this conclusion may be mistaken. Looking at the very long term, it may be possible to identify connections between immigration and other social, economic, and political variables that can be projected with some confidence. The difference is analogous to forecasting waves versus forecasting the tides. Much progress might be achievable if the abundance of available explanatory insights about immigration could somehow be consolidated and integrated into a useable projection method. The stakes are high given the growing importance of immigration in the population projection equation and the high degree of uncertainty surrounding it.

Progress will not come without a great deal of effort. It might require a multistage, multi-year effort that would bring together immigration theorists and researchers from around the world. The goal would be the construction of a long-term, multi-variant projection model. The overall approach might be neoclassical in its formal organization, but it would have to freely allow for the dynamic impact of any number of nonneoclassical elements.

Any long-term projection model would have to address the basic choices posed in the introduction. It might to some extent make policy endogenous to the immigration projections, perhaps by identifying what global social and economic conditions may trigger more restrictive immigration policies. At every turn, the theoretical and empirical basis for modeling assumptions would have to be spelled out. As for the generation of stochastic projections, this is probably an innovation that should wait - at least until we have learned more about the central trend of the model's assumptions.

No one realistically thinks that social science is on the verge of constructing a "unified field theory" of immigration that takes into account all the dimensions of this extraordinarily complex phenomenon. Any model would be partial and approximate and

perhaps less than elegant. It would have to splice together or at least reach a compromise between hostile theoretical perspectives. Even this, however, would be a vast improvement over anything now attempted by current projection practice. 


\section{BIBLIOGRAPHY}

\section{PROJECTION PRACTICE}

\section{Global Projections}

\section{United Nations}

United Nations Population Division (1999), World Population Prospects: The 1998 Revision, Volumes I and II. New York.

United Nations Population Division (2002), World Population Prospects: The 2000 Revision, Volume III: Analytical Report. New York.

United Nations Population Division (2003), World Population Prospects: The 2002 Revision, Volumes I and II. New York.

United Nations Population Division (2004), World Population in 2300. New York.

United Nations Statistics Division (2004), United Nations Common Database. Available at http://unstats.un.org/unsd/cdb/cdb_help/cdb_quick_start.asp

\section{World Bank}

Bos, E., M. T. Vu, E. Massiah, and R. A. Bulatao (1994), World Population Projections 1994-95 Edition: Estimates and Projections with Related Demographic Statistics. Baltimore, MD: Johns Hopkins University Press.

World Bank (2004), World Development Indicators 2004. CD-ROM. Washington, DC.

\section{International Program Center, U.S. Census Bureau}

United States Census Bureau (McDevitt, T. M., K. A. Stanecki and P. O. Way) (1999), World Population Profile: 1998. Report WP/98, Washington, DC: U.S. Government Printing Office.

United States Census Bureau (Christension, M., T. M. McDevitt and K. A. Stanecki) (2004), Global Population Profile 2002. International Population Reports WP/02, Washington, DC: U.S. Government Printing Office.

\section{International Institute for Applied Systems Analysis}

International Institute for Applied Systems Analysis (2004), "Global Population Projections." Available at http://www.iiasa.ac.at/Research/POP/index.html 
Lutz, W. ed. (1996), The Future Population of the World: What Can We Assume Today? Revised Edition, Laxenburg: International Institute for Applied Systems Analysis.

Lutz, W., W.C. Sanderson, and S. Scherbov (1997), "Doubling of World Population Unlikely," Nature, Vol. 387, pp. 803-805.

Lutz, W., P. Saariluoma, W. C. Sanderson, and S. Scherbov (2000), New Developments in the Methodology of Expert-and Argument-Based Probabilistic Population Forecasting. Laxenburg: International Institute for Applied Systems Analysis.

Lutz, W., W.C. Sanderson, and S. Scherbov (2001), "The End of World Population Growth," Nature, Vol. 412, pp. 543-545.

Lutz, W., B. C. O’Neill and S. Scherbov (2003), "Europe's Population at a Turning Point," Science, Vol. 299, pp. 1991-1992.

Lutz, W., W. C. Sanderson and S. Scherbov eds. (2004), The End of World Population Growth in the 21 st Century: New Challenges for Human Capital Formation and Sustainable Development. London: Earthscan in association with International Institute for Applied Systems Analysis, Laxenburg.

\section{$\underline{\text { United States }}$}

\section{$\underline{\text { U.S. Census Bureau }}$}

(2000), "The Census Bureau on Prospects for US Population Growth in the Twenty-First Century," Documents, Population and Development Review, Vol. 26, No. 1, pp. 197-200.

Kolankiewicz, L. (2000), "Immigration, Population, and the New Census Bureau Projections," Backgrounder, Center for Immigration Studies, Washington, DC.

Mulder, T. J. (2002), "Accuracy of the U.S. Census Bureau National Population Projections and Their Respective Components of Change," Population Division Working Paper Series No. 50, U.S. Census Bureau.

United States Census Bureau (Hollmann, F. W., T. J. Mulder and J. E. Kallan) (2000), "Methodology and Assumptions for the Population Projections of the United States: 1999 to 2100," Population Division Working Paper No. 38, Washington, DC.

United States Census Bureau (2001), Interim Projections of the U.S. Population by Age, Sex, Race, and Hispanic Origin: Summary, Methodology and Assumptions. Washington, DC: Government Printing Office. 


\section{Social Security Administration}

Lee, R. (2000), "Long-Term Projections and the US Social Security System," Population and Development Review, Vol. 26, No. 1, pp. 137-143.

The 1999 Technical Panel on Assumptions and Methods (1999), Report to the Social Security Advisory Board. Social Security Administration, Washington, DC.

The 2003 Technical Panel on Assumptions and Methods (2003), Report to the Social Security Advisory Board. Social Security Administration, Washington, DC.

Social Security Administration (Bell, F. C.) (1997), Social Security Area Population Projections: 1997. Actuarial Study No. 112. Baltimore, MD.

Social Security Administration (2004), The 2004 Annual Report of the Board of Trustees of the Federal Old-Age and Survivors Insurance and Disability Insurance Trust Funds. Washington, DC.

\section{European Countries}

\section{$\underline{\text { Eurostat }}$}

Eurostat (2001a), "The Evaluation of Regional Population Projections for the European Union,” Eurostat Working Paper 3/2001/E/nº 9, Luxembourg.

Eurostat (2001b), "Long-term International Migration Scenarios for the European Economic Area,” Eurostat Working Paper E4/1997-6, Luxembourg.

Eurostat (2002a), "Analysis and Forecasting of International Migration by Gender, Age and Major Groups (Part II)," Eurostat Working Paper 3/1999/E/ nº 9, Luxembourg.

Eurostat (Shaw, C.) (2002b), "Latest National Migration Forecasts in Europe," Working Paper Submitted at the Eurostat Working Party on Demographic Projections, Luxembourg, 16-17 September.

Eurostat (2002c), Eurostat Population Projections 1995 and Revision 1999. Available at http://europa.eu.int/comm/eurostat/.

Eurostat (2003), "Analysis and Forecasting of International Migration by Major Groups (Part III)," Working Paper 3/2002/E/no17, Luxembourg.

Salt, J., and A. Singleton (1995), Analysis and Forecasting of International Migration by Major Groups. Report prepared on behalf of Eurostat, Migration Research Unit, University College of London. 


\section{Federal Statistical Office of Germany}

Federal Statistical Office of Germany (Nagel, J., B. Sommer and O. Pötzsch) (2003), Population of Germany Today and Tomorrow. Wiesbaden.

\section{Statistics Netherlands}

de Beer, J. and M. Alders (1999), 'Probabilistic Population and Household Forecasts for the Netherlands," Paper for the European Population Conference EPC99, 30 August-3 September 1999, the Hague.

Gjaltema, T. A. (2003), "Half a Century of Population Forecasting in the Netherlands," Papers de Demografia No. 236, Centre d'Estudis Demogràfics, Barcelona.

Statistics Netherlands (2003), Population Forecasts of the Netherlands, 2002-2050. Available at http://www.cbs.nl/en/.

\section{United Kingdom: Government Actuary's Department}

United Kingdom Government Actuary's Department (1993), Population Projections: A New Methodology for Determining Migration Assumptions. GAD Occasional Paper No. 42.

United Kingdom Government Actuary's Department and Office for National Statistics (2004), National Population Projections: 2002-based. London.

United Kingdom Office for National Statis tics (2004), International Migration: Migrants Entering or Leaving the United Kingdom and England and Wales, 2002. London.

\section{Other Developed Countries}

\section{Statistics Canada}

Statistics Canada (2001), Population Projections for Canada, Provinces and Territories, 2000-2026. Ottawa.

\section{Japan: National Institute of Population and Social Security Research}

National Institute of Population and Social Security Research (2002), Population

Projections for Japan: 2001-2050: With Long-range Population Projections: 2051-2100. Tokyo.

National Institute of Population and Social Security Research(2003), Population Statistics of Japan 2003. Tokyo. 
Takahashi, S., R. Kaneko, A. Ishikawa, M. Ikenoue and F. Mita (1999), "Population Projections for Japan: Methods, Assumptions and Results," Review of Population and Social Policy, No. 8, pp. 75-115.

\section{Projection Practice: General}

Ahlburg, D. A. and W. Lutz (1998), "Introduction: The Need to Rethink Approaches to Population Forecasts," Population and Development Review, Vol. 24, Supplement: Frontiers of Population Forecasting, pp. 1-14.

Ahlburg, A. A., W. Lutz and J. W. Vaupel (1998), "Ways to Improve Population Forecasting: What Should Be Done Differently in the Future," Population and Development Review, Vol. 24, Supplement: Frontiers of Population Forecasting, pp. 191-98.

Bongaarts, J. and R. A. Bulatao eds. (2000), Beyond Six Billion: Forecasting the World's Population. Washington, DC: National Academy Press.

de Beer, J. (2000), “Dealing with Uncertainty in Population Forecasting,” Demographic Working Papers, Department of Population, Statistics Netherlands.

Goldstein, J. R. and G. Stecklov (2002), "Long-Range Population Projections Made Simple," Population and Development Review, Vol. 28, No. 1, pp. 121-141.

Kielman, N. (1998), "How Accurate are the United Nations World Population Projections?" Population and Development Review, Vol. 24, Supplement: Frontiers of Population Forecasting, pp. 15-41.

Kielman, N. and H. Cruijsen eds. (1992), National Population Forecasting in Industrialized Countries. Berwyn, PA: Swets \& Zeitlinger Inc.

Lee, R. (1998), "Probabilistic Approaches to Population Forecasting," Population and Development Review, Vol. 24, Supplement: Frontiers of Popula tion Forecasting, pp. 156-190.

O’Neill, B. and D. Balk (2001), "World Population Futures," Population Bulletin, Vol. 56, No. 3, pp. 3-40.

O’Neill, B., D. Balk, M. Brickman and M. Ezra (2001), "A Guide to Global Population Projections," Demographic Research, Vol. 4, No.8, pp. 203-288.

Passel, J. S. and R. Suro (2003), The Rise of the Second Generation: Changing Patterns in Hispanic Population Growth. Washington, DC: Pew Hispanic Center. 
Rees, P. and I. Turton (1998), "Investigation of the Effects of Input Uncertainty on Population Forecasting," Paper prepared for the $3^{\text {rd }}$ International Conference on GeoComputation, University of Bristol, United Kingdom, 17-19 August.

\section{IMMIGRATION THEORY}

\section{Policy Framework}

Burns, P. and J. G. Gimpel (2000), "Economic Insecurity, Prejudicial Stereotypes, and Public Opinion on Immigration Policy," Political Science Quarterly, Vol. 115, No. 2, pp. 201-225.

Cornelius, W. A. (1989), 'Impacts of the 1986 US Immigration Law on Emigration from Rural Mexican Sending Communities," Population and Development Review, Vol. 15, No. 4, pp. 689-705.

Cornelius, W. A., T. Tsuda, P. L. Martin and J. F. Hollifield eds. (2004), Controlling Immigration: A Global Perspective. 2nd Edition, Stanford, CA: Stanford University Press.

Espenshade, T. J. (1990), "Undocumented Migration to the United States: Evidence from a Repeated Trials Model," in F. D. Bean, B. Edmonston and J. S. Passel eds., Undocumented Migration to the United States: IRCA and the Experience of the 1980s. Washington, DC: The Urban Institute Press, pp. 159-181.

Espenshade, T. J. (1994), "Does the Threat of Border Apprehension Deter Undocumented US Immigration?" Population and Development Review, Vol. 20, No. 4, pp. 871-892.

Espenshade, T. J. and K. Hempstead (1996), “Contemporary American Attitudes Toward U.S. Immigration,” International Migration Review, Vol. 30, No. 2, pp. 535-570.

Freeman, G. P. (1992), "Migration Policy and Politics in the Receiving States," International Migration Review, Vol. 26, No. 4, pp. 1144-1167

Massey, D. S. (1999), "International Migration at the Dawn of the Twenty-First Century: The Role of the State," Population and Development Review, Vol. 25, No. 2, pp. 303-322.

Money, J. (1997), “No Vacancy: The Political Geography of Immigration Control in Advanced Industrial Countries," International Organization, Vol. 51, No. 4, pp. 685-720.

Money, J. (1999), Fences and Neighbors: The Political Geography of Immigration Control. Ithaca, NY: Cornell University Press. 
Simon, R. J. and J. P. Lynch (1999), “A Comparative Assessment of Public Opinion Toward Immigrants and Immigration Policies," International Migration Review, Vol. 33, No. 2, pp. 455-467.

Todaro, M. P and L. Maruszko (1987), "Illegal Migration and US Immigration Reform: A Conceptual Framework," Population and Development Review, Vol. 13, No. 1, pp. 101-114.

\section{$\underline{\text { Neoclassical Framework }}$}

Becker, G. S. (1962), "Investment in Human Capital: A Theoretical Analysis," Journal of Political Economy, Vol. 70, Supplement, Part 2, pp. 9-49.

Blomquist, G. C., M. C. Berger and J. P. Hoehn (1988), "New Estimates of Quality of Life in Urban Areas," The American Economic Review, Vol. 78, No.1, pp. 89107.

Borjas, G. J. (1987), "Self-Selection and the Earnings of Immigrants," The American Economic Review, Vol. 77, No. 4, pp. 531-553.

Borjas, G. J. (1989), "Economic Theory and International Migration," International Migration Review, Vol. 23, No. 3, Special Silver Anniversary Issue: International Migration an Assessment for the 90's, pp. 457-485.

Borjas, G. J., S. Bronars and S. Trejo (1992), "Assimilation and the Earnings of Young Internal Migrants," The Review of Economics and Statistics, Vol. 74, No. 1, pp. 170-175.

Brücker, H. and B. Siliverstovs (2004), "On the Estimation and Forecasting of International Migration: How Relevant Is Heterogeneity Across Countries?" German Institute for Economic Research (DIW), Berlin.

Chiquiar, D. and G. H. Hanson (2002), "International Migration, Self-Selection, and the Distribution of Wages: Evidence from Mexico and the United States," NBER Working Papers No. 9242.

Chis wick, B. R. (1984), "Illegal Aliens in the United States Labor Market: Analysis of Occupational Attainment of Earnings," International Migration Review, Vol. 18, No. 3, pp. 714-732.

Chiswick, B. R. (1999), 'Immigration Policy and Immigrant Quality: Are Immigrants Favorably Self-Selected?" The American Economic Review, Vol. 89, No. 2, pp. 181-185. 
Greenwood, M. J. (1975), "Research on International Migration in the United States: A Survey," Journal of Economic Literature, Vol. 13, No. 2, pp. 397-433.

Greenwood, M. J., J. R. Ladman and B. Siegel (1981), "Long-Term Trends in Migratory Behavior in a Developing Country: The Case of Mexico," Demography, Vol. 18, No. 3, pp. 369-388.

Harris, J. R and M. P. Todaro (1970), "Migration, Unemployment and Development: A Two-Sector Analysis," The American Economic Review, Vol. 60, No. 1, pp. 126142.

Hicks, J. R. (1932), The Theory of Wages. London: Macmillian.

Jewell, R. T. and D. J. Molina (2004), "Mexican Migration to the US: A Comparison of Income and Network Effects," Department of Economics Working Papers, University of North Texas, Denton, TX.

Lewis, W. A. (1954), "Economic Development with Unlimited Supplies of Labour," The Manchester School, Vol. 22, pp. 139-191.

Ranis, G. and J. C. H. Fei (1961), "A Theory of Economic Development," The American Economic Review, Vol. 51, No. 4, pp. 533-565.

Ravenstein, E. G. (1885), The Laws of Immigration. London: Royal Statistical Society.

Sjaastad, L. A (1962), “The Costs and Returns of Human Capital," The Journal of Political Economy, Vol. 70, No. 5, Part 2: Investment in Human Beings, pp. 8093.

Todaro, M. P. (1969), “A Model of Labor Migration and Urban Unemployment in Less Developed Countries," The American Economic Review, Vol. 59, No. 1, pp. 138148.

\section{World Systems Framework}

Frank, A. G. (1967), Capitalism and Underdevelopment in Latin America. New York: Monthly Review Press.

Friedmann, J. (1986), “The World City Hypothesis,” Development and Change, Vol. 17, No. 1, pp. 69-83.

Hatton T. J. and J. G. Williamson (1994), "What Drove the Mass Migrations from Europe in the Late Nineteenth Century?" Population and Development Review, Vol. 20, No. 3, pp. 533-559. 
Massey, D. S. (1988), "Economic Development and International Migration in Comparative Perspective," Population and Development Review, Vol. 14, No. 3, pp. 383-413.

Massey, D. S. (1990), "Social Structure, Household Strategies and the Cumulative Causation of Migration," Population Index, Vol. 56, No. 1, pp. 3-26.

Myrdal, G. (1957), Economic Theory and Underdeveloped Regions. London: Duckworth.

Portes, A. and R. G. Rumbaut (1996), Immigrant America: A Portrait. Berkeley: University of California Press.

Portes, A. and J. Walton (1981), Labor, Class, and the International System. New York: Academic Press.

Rumbaut, R. G. (1991), "Passages to America: Perspectives on the New Immigration," in A. Wolfe ed., America at Century's End. Los Angeles: University of California Press, pp. 208-244.

Sassen, S. (1988), The Mobility of Labor and Capital: A Study in International Investment and Labor Flow. New York: Cambridge University Press.

Wallerstein, I. (1974), The Modern World System: Capitalist Agriculture and the Origins of the European World-Economy in the Sixteenth Century. New York: Academic Press.

Wallerstein, I. (1996), “The Rise and Future Demise of World-Systems Analysis,” Paper delivered at the $91^{\text {st }}$ Annual Meeting of the American Sociological Association, New York, 16 August.

Zolberg, A. R., A. Suhrke and S. Aguayo (1989), Escape from Violence: Conflict and the Refugee Crisis in the Developing World. New York: Oxford University Press.

\section{$\underline{\text { New Economics Framework }}$}

Agarwal, R. and A. W. Horowitz (2002), "Are International Remittances Altruism or Insurance?: Evidence from Guyana Using Multiple-Migrant Households," World Development, Vol. 30, No. 11, pp. 2033-2044.

Barham, B. and S. Boucher (1998), "Migration, Remittances, and Inequality: Estimating the Net Effects of Migration on Income Distribution," Journal of Development Economics, Vol. 55, No. 2, pp. 307-331.

Beine, M., F. Docquier and H. Rapoport (2001), "Brain Drain and Economic Growth: Theory and Evidence," Journal of Development Economics, Vol. 64, No. 1, pp. 275-289. 
Conway, D. and J. H. Cohen (1998), "Consequences of Migration and Remittances for Mexican Transnational Communities," Economic Geography, Vol. 74, No. 1, pp. 26-44.

Durand, J., W. Kandel, E. A. Parrado and D. S. Massey (1996), "International Migration and Development in Mexican Communities," Demography, Vol. 33, No. 2, pp. 249-264.

Lauby, J. and O. Stark (1988), "Individual Migration as a Family Strategy: Young Women in the Philippines," Population Studies, Vol. 42, No. 3, pp. 473-786.

Lipton, M. (1980), "Migration From Rural Areas of Poor Countries: The Impact on Rural Productivity and Income Distribution," World Development, Vol. 8, No. 1, pp. 124.

Poirine, B. (1997), "A Theory of Remittances as an Implicit Family Loan Arrangement," World Development, Vol. 25, No. 4, pp. 589-611.

Rosenzweig, M. R. and O. Stark (1989), "Consumption Smoothing, Migration, and Marriage: Evidence from Rural India," The Journal of Political Economy, Vol. 97, No. 4, pp.905-926.

Stark, O. (1991), "Migration in LDCS: Risk, Remittances, and the Family," Finance and Development, Vol. 28, No. 4, pp. 39-41.

Stark, O. (2004), "Rethinking the Brain Drain," World Development, Vol. 32, No. 1, pp. 15-22.

Stark, O. and D. E. Bloom (1985), "The New Economics of Labor Migration," The American Economic Review, Vol. 75, No. 2, Papers and Proceedings of the Ninety-Seventh Annual Meeting of the American Economic Association, pp. 173178.

Stark, O., R. E. B. Lucas (1988), "Migration, Remittances, and the Family," Economic Development and Cultural Change, Vol. 36, No. 3, pp. 465-481.

Stark, O. and J. E. Taylor (1989), "Relative Deprivation and International Migration," Demography, Vol. 26, No. 1, pp. 1-14.

Stark, O. and J. E. Taylor (1991), "Migration Incentives, Migration Types: The Role of Relative Deprivation," The Economic Journal, Vol. 101, No. 408, pp. 1163-1178.

Stark, O., J. E. Taylor and S. Yitzhaki (1986), "Remittances and Inequality," The Economic Journal, Vol. 96, No. 383, pp. 722-740. 
Taylor, J.E. (1992), "Remittances and Inequality Reconsidered: Direct, Indirect, and Intertemporal Effects," Journal of Policy Modeling, Vol. 14, No. 2, pp. 187-208.

Taylor, J. E. (1999), “The New Economics of Labor Migration and the Role of Remittances in the Migration Process," International Migration, Vol. 37, No. 1, pp. 63-88.

\section{Social Network Framework}

Aguilera, M. B. and D. S. Massey (2003), "Social Capital and the Wages of Mexican Migrants: New Hypotheses and Tests," Social Forces, Vol. 82. No. 2, pp. 671701.

Boyd, M. (1989), "Family and Personal Networks in International Migration: Recent Developments and New Agendas," International Migration Review, Vol. 23, No. 3, pp. 638-670.

Carrington, W. J., E. Detragiache and T. Vishwanath (1996), "Migration and Endogenous Moving Costs," The American Economic Review, Vol. 86, No. 4, pp. 909-930.

Choldin, H. M. (1973), "Kinship Networks in the Migration Process," International Migration Review, Vol. 7, No. 2, pp. 163-175.

Coleman, J. S. (1988), "Social Capital in the Creation of Human Capital," The American Journal of Sociology, Vol. 94, Supplement: Organizations and Institutions: Sociological and Economic Approaches to the Analysis of Social Structure, pp. S95-S120.

Goss, J. and B. Lindquist (1995), "Conceptualizing International Labor Migration: A Structuration Perspective," International Migration Review, Vol. 29, No. 2, pp. 317-351.

Gurak, D. T. and F. Caces (1992), "Migration Networks and the Shaping of Migration Systems," in M. Kritz, L. Lim and H. Zlotnik eds., International Migration Systems: A Global Approach. London: Oxford University Press, pp. 150-176.

Hugo, G. J. (1981), "Village-Community Ties, Village Norms, and Ethnic and Social Networks: A Review of Evidence from the Third World," in G. F. De Jong and R. W. Gardner eds., Migration Decision Making: Multidisciplinary Approaches to Microlevel Studies in Developed and Developing Countries. New York: Pergamon Press, pp. 186-225.

Jasso, G. and M. R. Rosenzweig (1986), "Family Reunification and the Immigration Multiplier: U.S. Immigration Law, Origin-Country Cond itions, and the Reproduction of Immigrants," Demography, Vol. 23, No.3, pp. 291-311. 
Kandel, W. and D. S. Massey (2002), “The Culture of Mexican Migration: A Theoretical and Empirical Analysis," Social Forces, Vol. 80, No. 3, pp. 981-1004.

Massey, D. S. (1987), "Understanding Mexican Migration to the United States," The American Journal of Sociology, Vol. 92, No. 6, pp. 1372-1403.

Massey, D. S. and K. E. Espinosa (1997), "What's Driving Mexico-U.S. Migration? A Theoretical, Empirical, and Policy Analysis," The American Journal of Sociology, Vol. 102, No. 4, pp. 939-999.

Massey, D. S. and F. Garcia-Espana (1987), “The Social Process of International Migration,” Science, Vol. 237, No. 4816, p. 733.

Massey, D. S., L. Goldring and J. Duranc (1994), "Continuities in Transnational Migration: An Analysis of Nineteen Mexican Communities," The American Journal of Sociology, Vol. 99, No. 6, pp. 1492-1533.

Massey, D. S. and J. A. Phillips (1999), "The New Labor Market: Immigrants and Wages after IRCA,”Demography, Vol. 36, No. 2, pp. 233-246.

Massey, D. S. and J. A. Phillips (2000), "Engines of Immigration: Stocks of Human and Social Capital in Mexico," Social Science Quarterly, Vol. 81, No. 1, pp. 33-48.

Massey, D. S. and R. M. Zenteto (1999), "The Dynamics of Mass Migration,"

Proceedings of the National Academy of Sciences of the Unites States of America, Vol. 96, No. 9, pp. 5328-5335.

Montgomery, J. D. (1991), "Social Networks and Labor-Market Outcomes: Toward an Economic Analysis," The American Economic Review, Vol. 81, No. 5, pp. 14081418.

Munshi, K. (2003), "Networks in the Modern Economy: Migrants in the U.S. Labor Market," The Quarterly Journal of Economics, Vol.118, No. 2, pp. 549-599.

\section{Dual Labor Market Framework}

Beck, E. M., P. Horan and C. M. Tolbert, II (1980), "Social Stratification in Industrial Society: Further Evidence for Structural Alternative," American Sociological Review, Vol. 45, No. 4, pp. 712-719.

Cain, G. (1976), "The Challenge of Segmented Labor Market Theories to Orthodox Theory: A Survey," Journal of Economic Literature, Vol. 14, No.4, pp. 12151257. 
Dickens, W. T. and K. Lang (1988), "The Reemergence of Segmented Labor Market Theory," The American Economic Review, Vol. 78, No. 2, pp. 129-134.

Hodson, R. and R. L. Kaufman (1982), "Economic Dualism: A Critical Review," American Sociological Review, Vol. 47, No. 6, pp. 727-739.

Leontaridi, M. R. (1998), "Segmented Labor Markets: Theory and Evidence," Journal of Economic Surveys, Vol. 12, No. 1, pp. 63-101.

Logan, J. R., W. Zhang and R. D. Alba (2002), "Immigrant Enclaves and Ethnic Communities in New York and Los Angeles," American Sociological Review, Vol. 67, No. 2, pp. 299-322.

Mata, F. and R. Pendakur (1999), "Immigration, Labor Force Integration and the Pursuit of Self-Employment," International Migration Review, Vol. 33, No. 2, pp. 378402.

Müller, T. (2001), "Migration, Unemployment and Discrimination," European Economic Review, Vol. 47, No. 3, pp. 409-427.

Piore, M. J. (1979), Birds of Passage: Migrant Labor and Industrial Societies. New York: Cambridge University Press.

Piore, M. J. (1986), “The Shifting Grounds for Immigration,” Annals of the American Academy of Political and Social Science, Vol. 485, pp. 23-33.

Wachter, M.L., R. A. Gordon, M. J. Piore and R. E. Hall (1974), "Primary and Secondary Labor Markets: A Critique of the Dual Approach," Brookings Papers on Economic Activity, Vol. 1974, No. 3, pp. 637-693.

\section{Immigration Theory: General}

Clark, X., T. J. Hatton and J. G. Williamson (2004), "Explaining US Immigration 19711998," World Bank Policy Research Working Paper 3252, March.

Jennissen, R. (2000), "Can Economic Determinants Improve the Theoretical Background for International Migration Hypothesis?” NIDI Working Papers No. 2000/02.

Massey, D. S. (2003), "Patterns and Processes of International Migration in the $21^{\text {st }}$ Century," Paper prepared for the Conference on African Migration in Comparative Perspective, Johannesburg, South Africa, 4-7 June.

Massey, D. S., J. Arango, G. Hugo, A. Kouaouci, A. Pellegrino and J. E. Taylor (1993), "Theories of International Migration: A Review and Appraisal," Population and Development Review, Vol. 19, No. 3, pp. 431-466. 
Massey, D. S., J. Arango, G. Hugo, A. Kouaouci, A. Pellegrino, and J. E. Taylor (1994), "An Evaluation of International Migration Theory: The North American Case," Population and Development Review, Vol. 20, No. 4, pp. 699-751.

Massey, D. S., J. Arango, G. Hugo, A. Kouaouci, A. Pellegrino and J. E. Taylor (1998), Worlds in Motion: Understanding International Migration at the End of the Millennium. Oxford: Clarendon Press.

Teitelbaum, M. S. (2001), "International Migration: Predicting the Unknowable," Ch. 1 in M. Weiner and S. S. Russell eds., Demography and National Security. New York: Berghahn Books, pp. 21-37.

Zimmerman, K. F. and T. Bauer eds. (2002), The Economics of Migration, Vols. I-IV, The International Library of Critical Writings in Economics, Vol. 151. Northampton, MA: Edward Elgar Publishing Inc.

Zoltnik, H. (1998), "International Migration 1965-1996: An Overview," Population and Development Review, Vol. 24, No. 3, pp. 429-468.

\section{MISCELLANEOUS}

Bouvier, L. F. (1998), “The Impact of Immigration on United States' Population Size: 1950-2050,” NPG Forum Series, November Issue.

Bouvier, L. F., D. L. Poston, Jr. and N. B. Zhai (1997), "Population Growth Impacts of Zero Net International Migration," International Migration Review, Vol. 31, No. 2, pp. 294-311.

Castles, S. and M. J. Miller (1993), The Age of Migration: International Population Movements in the Modern World. New York: Guilford Press.

Espenshade, T. J., L. F. Bouvier and W. B. Arthur (1982), "Immigration and the Stable Population Model,” Demography, Vol. 19, No. 1, pp. 125-133.

European Commission (2000), Push and Pull Factors of International Migration: A Comparative Report. Luxembourg: Office for Official Publications of the European Communities.

Lutz, W. and S. Scherbov (2003), "Future Demographic Change in Europe: The Contribution of Migration," Interim Report IR-03-066, Laxenburg: International Institute for Applied Systems Analysis.

Martin, P. (2003), "Immigration and Integration: The Transatlantic Challenge," Prepared for the Bertelsmann Foundation Transatlantic Initiative. 
Martin, P. and E. Midgley (1999), "Immigration to the United States," Population Bulletin, Vol. 54, No. 2.

Martin, P. and E. Midgley (2003), "Immigration Shaping and Reshaping America," Population Bulletin, Vol. 58, No. 2.

Martin, P. and J. Widgren (2002), "International Migration: Facing the Challenge," Population Bulletin, Vol. 57, No. 1

Massey, D. S., J. Durand and N. J. Malone (2002), Beyond Smoke and Mirrors: Mexican Immigration in an Era of Economic Integration. New York: Russel Sage Foundation.

Riche, M. F. (2000), “America's Diversity and Growth: Signposts for the $21^{\text {st }}$ Century," Population Bulletin, Vol. 55, No. 2.

Tovar, E. M. L. and M. Susan (1997), Migration between Mexico and the United States: Binational Study. US Commission on Immigration Reform.

United Nations Population Division (2001), Replacement Migration: Is It a Solution to Declining and Ageing Populations? New York.

Visco, I. (2000), "Migration Scenarios for the $21^{\text {st }}$ Century: Immigration, Development and the Labour Market," prepared for the OECD International Conference in Rome, Italy, July 12-14.

Zlotnik, H. (1999), "Trends in International Migration since 1965: What Existing Data Reveal," International Migration, Vol. 37, No. 1, pp. 21-61. 


\section{RECENT WORKING PAPERS FROM THE CENTER FOR RETIREMENT RESEARCH AT Boston College}

Projecting Immigration: A Survey of the Current State of Practice and Theory Neil Howe and Richard Jackson, December 2004

Does Work Pay at Older Ages?

Barbara A. Butrica, Richard W. Johnson, Karen E. Smith, and Eugene Steuerle, November 2004

Poverty and Income Maintenance in Old Age: A Cross-National View of Low Income Older Women

Timothy M. Smeeding and Susanna Sandstrom, November 2004

How Does Marriage Affect the Allocation of Assets in Women's Defined Contribution Plans?

Angela C. Lyons and Tansel Yilmazer, November 2004

Why Don't Americans Save?

Barry Bosworth, November 2004

How Do Pensions Affect Expected and Actual Retirement Ages?

Alicia H. Munnell, Robert K. Triest, and Natalia A. Jivan, November 2004

Sliding Into Poverty? Cross-National Patterns of Income Source Change and Income Decay in Old Age

James M. Williamson and Timothy M. Smeeding, November 2004

The Well-Being Of Retirees: Evidence Using Subjective Data

Keith A. Bender, November 2004

The Impact of Aging on Financial Markets and the Economy: A Survey Barry P. Bosworth, Ralph C. Bryant and Gary Burtless, October 2004

Social Security Personal-Account Participation with Government Matching Gary V. Engelhardt and Anil Kumar, October 2004

All working papers are available on the Center for Retirement Research website (http://www.bc.edu/crr) and can be requested by e- mail (crr@bc.edu) or phone (617-552-1762). 